\title{
PPARGC1A Gene Product
}

National Cancer Institute

\section{Source}

National Cancer Institute. PPARGC1A Gene Product. NCI Thesaurus. Code C122779.

A protein encoded by the PPARGC1A gene. 